\title{
Front Matter: Volume 10493
}

, "Front Matter: Volume 10493," Proc. SPIE 10493, Dynamics and Fluctuations in Biomedical Photonics XV, 1049301 (10 May 2018); doi: $10.1117 / 12.2322675$

SPIE. Event: SPIE BiOS, 2018, San Francisco, California, United States 


\title{
Dynamics and Fluctuations in Biomedical Photonics XV
}

\author{
Valery V. Tuchin \\ Kirill V. Larin \\ Martin J. Leahy \\ Ruikang K. Wang \\ Editors
}

28-29 January 2018

San Francisco, California, United States

Sponsored and Published by

SPIE 
The papers in this volume were part of the technical conference cited on the cover and title page. Papers were selected and subject to review by the editors and conference program committee. Some conference presentations may not be available for publication. Additional papers and presentation recordings may be available online in the SPIE Digital Library at SPIEDigitallibrary.org.

The papers reflect the work and thoughts of the authors and are published herein as submitted. The publisher is not responsible for the validity of the information or for any outcomes resulting from reliance thereon.

Please use the following format to cite material from these proceedings:

Author(s), "Title of Paper," in Dynamics and Fluctuations in Biomedical Photonics XV, edited by Valery V. Tuchin, Kirill V. Larin, Martin J. Leahy, Ruikang K. Wang, Proceedings of SPIE Vol. 10493 (SPIE, Bellingham, WA, 2018) Seven-digit Article CID Number.

ISSN: 1605-7422

ISSN: 1996-756X (electronic)

ISBN: 9781510614710

ISBN: 9781510614727 (electronic)

Published by

SPIE

P.O. Box 10, Bellingham, Washington 98227-0010 USA

Telephone +1 3606763290 (Pacific Time) · Fax +1360647 1445

SPIE.org

Copyright @ 2018, Society of Photo-Optical Instrumentation Engineers.

Copying of material in this book for internal or personal use, or for the internal or personal use of specific clients, beyond the fair use provisions granted by the U.S. Copyright Law is authorized by SPIE subject to payment of copying fees. The Transactional Reporting Service base fee for this volume is $\$ 18.00$ per article (or portion thereof), which should be paid directly to the Copyright Clearance Center (CCC), 222 Rosewood Drive, Danvers, MA 01923. Payment may also be made electronically through CCC Online at copyright.com. Other copying for republication, resale, advertising or promotion, or any form of systematic or multiple reproduction of any material in this book is prohibited except with permission in writing from the publisher. The CCC fee code is 0277 $786 \mathrm{X} / 18 / \$ 18.00$.

Printed in the United States of America.

Publication of record for individual papers is online in the SPIE Digital Library.

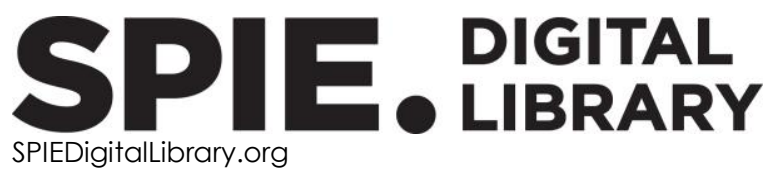

Paper Numbering: Proceedings of SPIE follow an e-First publication model. A unique citation identifier (CID) number is assigned to each article at the time of publication. Utilization of CIDs allows articles to be fully citable as soon as they are published online, and connects the same identifier to all online and print versions of the publication. SPIE uses a seven-digit CID article numbering system structured as follows:

- The first five digits correspond to the SPIE volume number.

- The last two digits indicate publication order within the volume using a Base 36 numbering system employing both numerals and letters. These two-number sets start with $00,01,02,03,04$, $05,06,07,08,09,0 A, 0 B \ldots$... Z, followed by 10-1Z, 20-2Z, etc. The CID Number appears on each page of the manuscript. 


\title{
Contents
}

\author{
vii Authors \\ ix Conference Committee \\ xiii Introduction
}

SPECKLE TECHNOLOGIES

1049303 Laser speckle imaging of brain blood flow through a transparent nanocrystalline yttriastabilized-zirconia cranial implant [10493-2]

1049304 Biodynamic imaging of therapeutic efficacy for canine B-cell lymphoma: preclinical trial results [10493-3]

1049305 Poincaré descriptors of long and short-range correlations in the spatial and temporal fluctuations of coherently scattered light [10493-4]

\section{FUNCTIONAL IMAGING AND SPECTROSCOPY I}

10493 OC Functional optical coherence tomography for live dynamic analysis of mouse embryonic cardiogenesis (Invited Paper) [10493-11]

10493 OD Optical coherence tomography angiography and cutaneous wound healing [10493-12]

10493 OG Heart rate sensitive optical coherence angiography [10493-70]

\section{CEREBRAL HEMO- LYMPHO- AND GLYMPHATIC DYNAMICS}

10493 ol Long-term in vivo monitoring of injury induced brain regeneration of the adult zebrafish by using spectral domain optical coherence tomography [10493-17]

\section{CLINICAL IMAGING AND EVALUATION}

1049300 Quantitative detection of breast ductal carcinoma tissues at different progression stages using Mueller matrix microscope [10493-23]

10493 OP In-vivo assessment of microvascular functional dynamics by combination of $\mathrm{cmOCT}$ and wavelet transform [10493-24] 
10493 OU A cost function approach for the analysis of time-resolved functional near-infrared spectroscopy (TR fNIRS) signals [10493-29]

\section{OPTICAL CLEARING AND BIOMECHANICS}

10493 0X The microstructural variation during tissue optical clearing by Mueller matrix polarimetry [10493-32]

10493 OY DAS: a simple, efficient, scalable and Dil-compatible optical clearing method for intact systems [10493-33]

\section{POSTER SESSION}

1049311 Control of epileptic seizures in WAG/Rij rats by means of brain-computer interface [10493-34]

1049314 Characterization of vascular dynamics based on experimental recordings with extreme data loss [10493-37]

1049315 Detection of EEG-patterns associated with real and imaginary movements using detrended fluctuation analysis [10493-38]

1049317 Nonlinear dynamics and coherent resonance in a network of coupled neural-like oscillators [10493-40]

1049319 The study of human higher mental functions as they relate to neurophysiological processes and personal characteristics [10493-42]

10493 1B Brain-computer interface for alertness estimation and improving [10493-48]

$104931 \mathrm{C}$ Nonlinear correlation method for the separation of couplings in EEG experiments with neural ensembles [10493-49]

10493 ID Effect of filtration of signals of brain activity on quality of recognition of brain activity patterns using artificial intelligence methods [10493-50]

10493 IF Multi-color backscattering Mueller matrix imaging on thick fresh tissues and on living nude mice skin [10493-52]

10493 IG Analysis of bistable perception based on MEG data [10493-53]

$104931 \mathrm{H}$ Use of parallel computing for analyzing big data in EEG studies of ambiguous perception [10493-54]

1049311 Study of the interactions in neural ensemble of the brain using wavelet analysis [10493-55] 
$104931 \mathrm{~K}$ Effect of luminescence transport through adipose tissue on measurement of tissue temperature by using ZnCdS nanothermometers [10493-57]

$10493 \mathrm{lL} \quad$ Fibre optic probe for fluorescence diagnostics with blood influence compensation [10493-58]

1049310 Monitoring skin microvascular dysfunction of type 1 diabetic mice using in vivo skin optical clearing [10493-61]

$104931 Q$ Identification of the patterns of brain activity during the imagination of movements using an artificial neural network [10493-63]

10493 IR Development and validation of factor analysis for dynamic in-vivo imaging data sets [10493-64]

10493 is High speed spatially resolved diffuse imaging for jet injection depth estimation [10493-66]

10493 1T Laser-assisted nanoceramics reinforced polymer scaffolds for tissue engineering: additional heating and stem cells behavior [10493-68] 
Proc. of SPIE Vol. 10493 1049301-6

Downloaded From: https://www.spiedigitallibrary.org/conference-proceedings-of-spie on 26 Apr 2023 Terms of Use: https://www.spiedigitallibrary.org/terms-of-use 


\section{Authors}

Numbers in the index correspond to the last two digits of the seven-digit citation identifier (CID) article numbering system used in Proceedings of SPIE. The first five digits reflect the volume number. Base 36 numbering is employed for the last two digits and indicates the order of articles within the volume. Numbers start with 00, 01, 02, 03, 04, 05, 06, 07, 08, 09, OA, OB...0Z, followed by 10-12, 20-2Z, etc.

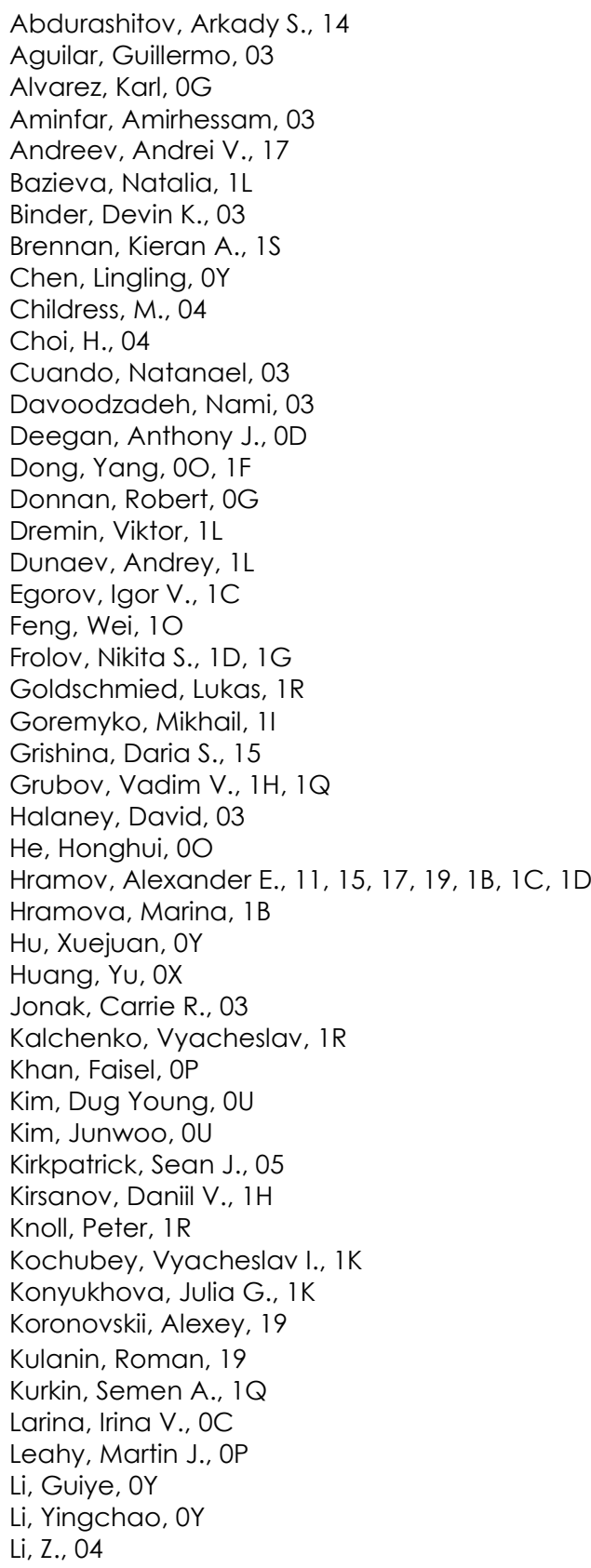

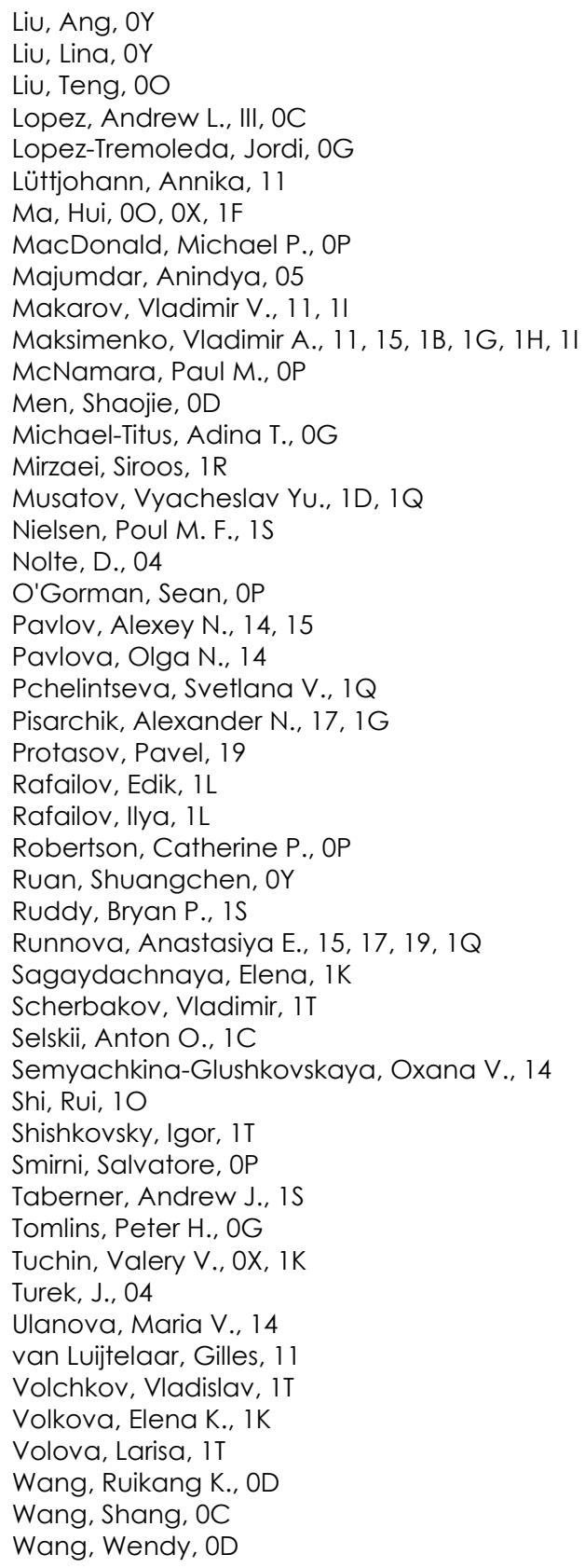


Xie, Qiaolin, OX

Yanina, Irina $Y U ., 1 K$

Yao, Yue, IF

Yuan, Zhen, 0

Zeng, Nan, OX

Zhang, Jian, 0

Zharkikh, Elena, $1 \mathrm{~L}$

Zherebtsov, Evgeny, 1L

Zherebtsova, Angelina, $1 \mathrm{~L}$

Zhu, Dan, 10

Zhu, Yuanhuan, IF

Zhuravlev, Maxim, 19 


\title{
Conference Committee
}

\author{
Symposium Chairs
}

James G. Fujimoto, Massachusetts Institute of Technology

(United States)

R. Rox Anderson, Wellman Center for Photomedicine, Massachusetts General Hospital (United States) and Harvard Medical School

(United States)

Program Track Chair

Steven L. Jacques, Tufts University (United States)

Conference Chairs

Valery V. Tuchin, N.G. Chernyshevsky Saratov National Research State University (Russian Federation), National Research Tomsk State University (Russian Federation), and Institute of Precision Mechanics and Control RAS (Russian Federation)

Kirill V. Larin, University of Houston (United States)

Martin J. Leahy, National University of Ireland, Galway (Ireland)

Ruikang K. Wang, University of Washington (United States)

\section{Conference Program Committee}

Wei R. Chen, University of Central Oklahoma (United States)

Joseph P. Culver, Washington University School of Medicine in St. Lovis (United States)

Turgut Durduran, ICFO - Institut de Ciències Fotòniques (Spain)

Ling Fu, Huazhong University of Science and Technology (China)

Ekaterina I. Galanzha, University of Arkansas for Medical Sciences (United States)

Jana M. Kainerstorfer, Carnegie Mellon University (United States)

Brendan F. Kennedy, The University of Western Australia (Australia)

Faisel Khan, University of Dundee (United Kingdom)

Vesa Kiviniemi, University of Oulu (Finland)

Jürgen M. Lademann, Charité Universitätsmedizin Berlin (Germany)

Irina V. Larina, Baylor College of Medicine (United States)

Jan Laufer, Martin-Luther-Universität Halle-Wittenberg (Germany)

Qingming Luo, Huazhong University of Science and Technology

(China)

Igor V. Meglinski, University of Oulu (Finland)

Melissa C. Skala, University of Wisconsin-Madison (United States)

Peter H. Tomlins, Queen Mary University of London (United Kingdom)

Vladislav Toronov, Ryerson University (Canada) 
Lihong V. Wang, California Institute of Technology (United States)

Anna N. Yaroslavsky, University of Massachusetts Lowell

(United States)

Vladimir P. Zharov, University of Arkansas for Medical Sciences

(United States)

Dan Zhu, Huazhong University of Science and Technology (China)

\section{Session Chairs}

1 Speckle Technologies

Wei R. Chen, University of Central Oklahoma (United States)

Anna N. Yaroslavsky, University of Massachusetts Lowell (United States)

Qingming Luo, Huazhong University of Science and Technology (China)

2 Tissue and Cell Dynamics

Martin J. Leahy, National University of Ireland, Galway (Ireland)

Vesa Kiviniemi, University of Oulu (Finland)

3 Keynote Session

Martin J. Leahy, National University of Ireland, Galway (Ireland)

4 Functional Imaging and Spectroscopy I

Turgut Durduran, ICFO - Institut de Ciències Fotòniques (Spain)

Vladimir P. Zharov, University of Arkansas for Medical Sciences (United States)

Vladislav Toronov, Ryerson University (Canada)

5 Cerebral Hemo- Lympho- and Glymphatic Dynamics

Dan Zhu, Huazhong University of Science and Technology (China)

Lihong V. Wang, California Institute of Technology (United States)

Jürgen Lademann, Charité Universitätsmedizin Berlin (Germany)

6 Clinical Imaging and Evaluation

Irina V. Larina, Baylor College of Medicine (United States)

Peter H. Tomlins, Queen Mary University of London (United Kingdom)

Igor Meglinski, University of Oulu (Finland)

7 Functional Imaging and Spectroscopy II

Brendan F. Kennedy, The University of Western Australia (Australia)

Jana M. Kainerstorfer, Carnegie Mellon University (United States)

Jan Laufer, Martin-Luther-Universität Halle-Wittenberg (Germany)

8 Optical Clearing and Biomechanics

Ling Fu, Huazhong University of Science and Technology (China) 


\section{Introduction}

This proceedings volume is from the conference, Dynamics and Fluctuations in Biomedical Photonics XV, held Sunday through Monday, 28-29 January 2018, at the SPIE Photonics West Symposium in San Francisco, California, (United States). It was a two-day meeting featuring one keynote, nine invited presentations, 22 oral presentations, and 31 poster presentations from leading international research groups. The goal of the conference was to gather essentially different groups of researchers such as biophysicists, medical doctors, physicians, and optical and laser engineers, together with students to discuss the current state of the art and to facilitate future progress in the development of biomedical optical and laser technologies based on dynamics and fluctuations approaches. The laser-speckle, speckle-based coherence imaging, microcirculation analysis and angiography using OCT and other optical techniques, dynamics of molecular diffusion, including nanoparticles, and tissue optical clearing in context of their application to biomedical science and clinics are always included in this annual meeting. These approaches should be useful for diagnosis and therapy of devastating lifethreatening diseases such as those of the heart, cancer, vascular, mental illness, and many others that manifest as a breach of the living organism's immune systems at the level of molecule, cell, organ, or organism as a whole. We hope that the proceedings of this conference will contribute to the development of such interdisciplinary fields of science and applications as dynamics and structures of living systems, biomedical optics and laser medicine, and that it will be useful to researchers, medical doctors, engineers, and students.

Several biophotonics techniques including Optical Coherence Tomography (OCT) and Photoacoustic Imaging (PAI) are rapidly impacting research, discovery, and clinical applications. The rapid development of functional extensions to these techniques is perhaps nowhere better illustrated than in angiography. Following a keynote lecture by one of the leaders of this field, we discussed what can, and should, be done by our community to provide and promote the necessary tools. Malfunction of blood flow is associated with diseases including diabetes, cancer, psoriasis, neurodegeneration and many others. Biophotonics is well placed to fill this need and many of our colleagues have already demonstrated techniques for this purpose. These include: Optical Coherence Tomography Angiography (OCTA), Intra-vital Microscopy, Photoacoustics and Multiphoton Microscopy. The panel discussion reviewed the state of the art and discussed what can and should be done by our community to provide the necessary tools to advance discovery, diagnosis, and therapy.

The panel discussion followed several related talks in the Dynamics and Fluctuations conference, including a wonderful keynote lecture by Prof. Ruikang Wang, University of Washington, (United States) on "Optical coherence tomography based angiography: principles and applications." Prof. Wang described the rapid advances of OCTA in ophthalmology, neuroscience, 
dermatology and the oral cavity. He provided an overview of the principles behind several of the OCTA techniques. Prof. Gereon Hüttmann and others had an interesting debate about the pulse wave velocity (PWV) in the retinal vessels. This is an indication of the stiffness of the vessels with correlation to several diseases. Until a recent paper by Prof. Hüttmann's group, there had been some uncertainty and even controversy surrounding the typical PWV ranging from sub $\mathrm{mm} / \mathrm{s}$ to $600 \mathrm{~mm} / \mathrm{s}$. It appears the real typical PWV is of the order of $50 \mathrm{~mm} / \mathrm{s}$. Bernard Choi emphasized the need for monitoring equipment that was informative, affordable, and unobtrusive in the clinic, and laser speckle techniques have advantages in these areas. Peter H. Tomlins, Queen Mary University of London (United Kingdom), outlined the use of high speed, 4D microangiography to aid discovery and diagnosis in traumatic brain injury and related diseases. He also discussed the need for a compact low-cost OCT system for periodontal investigations. Rainer Leitgeb, Medizinische Universität Wien (Austria), brought up the importance of high-speed imaging to support large field of view angiography as well as to support high resolution. The combination with adaptive optics allows for unprecedented vascular details and suppression of shadow artifacts. He also demonstrated the combination with photoacoustics to obtain a complete picture of tissue perfusion starting from superficial capillaries down to larger vessel networks over several millimiters in depth.

Perhaps the most exciting images and videos were those developed in Irina $\mathrm{V}$. Larina's, Baylor College of Medicine (United States) lab, showing the extraordinarily rapid development of the mammalian fetus, which in 9.5 days post-coitus has a fully formed beating heart with four chambers. These details were described by Kirill V. Larin, University of Houston (United States), whose group obtained and rendered the images and videos obtained from the mammalian mouse model in Prof. Larina's lab at Baylor College of Medicine. Several challenges were overcome for longitudinal monitoring of the fetuses and to obtain clear images, such as cardiac gating so that the heart would be in a similar position for several scans. Not only is the blood flow visible, but the typically hyperbolic velocity profile can also be seen using OCTA. The model provides a much needed resource to study diseases and disorders of early developmental origin. Many of the details of mammalian development can be studied, including the blood supply to the crystalline lens of the eye, which is only present during development, defects in limb or heart development, development and remodeling of yolk sac and embryonic brain vasculature etc. The ability of speckle variance OCT to monitor fetal brain vasculature was shown as equal to that of Doppler OCT for vessels horizontal to the beam and superior when the vessels approached the axial direction. In a further demonstration of the power of this technique and model, Prof. Larin revealed that alcohol exposure caused the arteries to constrict and reduced fetal brain flow by approximately $50 \%$. In addition to the selected panel of experts, others contributed their opinions, insights and questions to make this a lively and informative discussion.

Most of the conference sessions featured invited presentations. These presentations drew significant attention from the audience and resulted in wide 
coffee break discussions. They provided a nice overview of recent advances in multiple fields of biomedical optics and biophotonics related to dynamic and fluctuation research. The oral sessions and corresponding poster session featured many presentations that described different methods and techniques developed and applied to study complex problems of dynamics and fluctuations in biological systems on the scale ranging from cell to the whole body. The reader is encouraged to browse the table of contents for this issue to learn the full scope of the conference.

The conference chairs would like to thank the members of the Technical Program Committee for their help in organizing the conference. We sincerely appreciate the support of SPIE and conference staff. Finally, we would like to thank all of the conference attendees and manuscript authors for their contributions and participation, especially invited and keynote speakers, and panelists who helped to make this meeting a success.

\author{
Valery V. Tuchin \\ Kirill V. Larin \\ Martin J. Leahy \\ Ruikang K. Wang
}


Proc. of SPIE Vol. 10493 1049301-14 Downloaded From: https://www.spiedigitallibrary.org/conference-proceedings-of-spie on 26 Apr 2023
Terms of Use: https://www.spiedigitallibrary.org/terms-of-use 